\title{
PERILAKU EKSPOR DAN PRODUKTIVITAS PADA USAHA MANUFAKTUR MIKRO DAN KECIL DI INDONESIA: PENDEKATAN MODEL LIMITED DEPENDENT
}

\author{
EXPORT BEHAVIOR AND PRODUCTIVITY IN MICRO AND SMALL \\ MANUFACTURING FIRMS IN INDONESIA: LIMITED DEPENDENT MODEL \\ APPROACHES
}

\section{Edi Kiswanto}

MPKP FEB Universitas Indonesia, Jl. Salemba Raya No.4, Jakarta Pusat, 10430, Indonesia

\begin{tabular}{l}
\hline ARTICLE INFORMATION \\
\hline Article history: \\
Received: November 18, 20 \\
Revised: February 26, 21 \\
Accepted: March 13, 21 \\
\\
\hline Keywords: \\
Export behavior \\
Indonesia \\
Productivity \\
SMEs \\
\\
*Corresponding Author \\
Name : Edi Kiswanto \\
E-mail: edi.kiswanto.ui@gmail.com
\end{tabular}

\section{A B S T R A C T}

This study examines the role of productivity in explaining Indonesian micro and small manufacturing firms' export behavior based on a firm-level dataset of micro and small manufacturing survey year 2015 (VIMK15) from Statistics Indonesia. By utilizing the Probit and Tobit model, this study analyses the role of the firm's productivity, which is proxied by labor productivity and output to cost ratio, on determining firms' export participation and intensity. The other factor related to productivity and firms' characteristic is also used as control variables. This study found that labor productivity and output to cost ratio positively and significantly determine export participation and intensity even though its marginal effect plays a minor role in the export behavior. Besides, as measured by CEO education and employment training, human capital contributes a major impact on encouraging firms to participate in the export market. Therefore, providing appropriate and reasonable employee training might support Indonesian micro and small manufacturing firms' development.

This is an open access article under the $\underline{\mathrm{CC}-\mathrm{BY}}$ license.

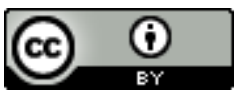

\section{INTRODUCTION}

In the development of regional integration, the Association of Southeast Asian Nations (ASEAN) proposes the economic community blueprint 2025. One of their concern is a new emphasis on the development and promotion of micro, small, and medium enterprises (SMEs) in its economic integration. SMEs are considered as one of the central drivers to promote equitable economic development within the ASEAN region. Moreover, they are also perceived as the engine of economic growth because they can create employment, produce outputs, and increase the aggregate demand [1].
This development provides both opportunities and challenges for SMEs in ASEAN countries. On the one side, they have the prospect of expanding their business in the regional market. On the other hand, they must compete with other SMEs in ASEAN countries. Therefore, SMEs of ASEAN countries need to progress their productivity to exist in a competitive and integrated region.

In Indonesia, SMEs have a central role in the national economy. According to Statistic Indonesia and the Ministry of Cooperatives and SMEs' data, SMEs dominate the firm structure for about $99 \%$ of total business entities on average from 2010 to 2018. Moreover, they also contribute around $97 \%$ of national employment in the same 
period. Nevertheless, their contribution to Gross Domestic Product (GDP) and exports are still considered underperformed, regardless of their massive share of its number and employment. From 2010 through 2018, SMEs contributed to GDP and exports by about $57 \%$ and $15 \%$, respectively. It means that SMEs in Indonesia are indicated to encounter lower productivity than large enterprises [2]. Moreover, according to the Asian Development Bank [3], Indonesian SMEs' contribution to export is still relatively small among ASEAN peer countries.

The relationship between productivity and export behavior has become an interesting and important issue. It can be seen from the abundant studies regarding the relationship between those variables in the international trade literature. Wagner [4] and Haidar [5] state that productivity and export have two different relationships. The first is the self-selection, and the second is the learning by exporting hypothesis.

The self-selection hypothesis means that productive firms are more likely to become exporters and participate in the export market. Exporting engagement requires additional costs such as transportation cost, production costs to meet international markets' requirements, distribution and marketing fees, and tariffs. Therefore, only productive firms will take advantage of entering the export market.

Many empirical results support the self-selection hypothesis. Bernard and Jensen [6] found that exporters have productive characteristics before taking up export activities. Delgado, Farinas, and Ruano [7] apply non-parametric methods on a panel of Spanish firms. Their results support the self-selection mechanism. The highly productive firms more likely to participate in the export market, while the evidence for learning effects is not significant. Another important study, Arnold and Hussinger [8], examines the causal relationship between productivity and exporting in German manufacturing. The result arranges that firms with high productivity tend to participate in the export market while exporting activity does not play a critical role in firm productivity. MonrealPérez, Aragón-Sánchez, and Sánchez-Marín [9] also find strong evidence for self-selection in their data from Spanish manufacturing firms from 2001 to 2008 .

Furthermore, Deshmukh and Pyne [10] study the relationship between firms' productivity and export capability. The authors use the firm-level data from India's manufacturing industries during 1991-
2009. The study also found empirical evidence in favor of the self-selection hypothesis.

On the other hand, learning by exporting hypothesis means that exporting activities will encourage firms to produce more efficiently. After participating in the export market, firms gain more efficiency because of the transfer of knowledge and technology between exporters and customers. However, the empirical evidence that supports the learning by exporting hypothesis has not met the consensus.

Furthermore, this study follows the self-selection hypothesis since it has been supported by consensus empirical evidence. Studies and research related to the firm's productivity and export behavior are relatively ample. Cassiman, Golovko, and Martínez-Ros [11] argue that productivity and export have a positive association and relate to firms' innovation. The study uses a panel of Spanish manufacturing firms running from 1990 until 1998. The authors suggest that product innovation affects productivity and encourages firms to participate in the export market. Todo [12] examines the determinants of the export and foreign direct investment decision. The author used a firm-level dataset for Japan based on the Basic Survey of Enterprise Activities over 1997-2005. The study explains the importance of firms' productivity and characteristics, such as firms' size and previous export experience, on export participation.

Moreover, Srinivasan and Archana [13] examine the determinants of firms' export decisions. The authors use Indian firm-level data and found that firms' productivity, firm's size, and level barriers to trade determine its export decision. Then, Ricci and Trionfetti [14] study the effect of productivity and networking on the firm's export probability. The paper uses a multi-country and multi-industry firmlevel dataset based on a World Bank survey of an economy's private sector. The authors found that productive and larger firms are more likely to be exporters. Another critical study, Mallick and Yang [15], examines the effect of productivity on exporting behavior in Indian firms during 19892009. The study found that exporter firms are more productive than non-exporters.

Meantime, studies related to productivity and SME's export behavior are infrequent. It might be due to the limited export activities of SMEs. Amornkitvikai, Harvie, and Charoenrat [16] investigate the factor affecting Thai SMEs' export behavior. The authors use a dataset from the Thai Industrial Census year 2007. The study explains 
that export participation of manufacturing SMEs in Thailand is determined by factors and characteristics such as labor productivity, firms' age, firms' size, skilled labor, assistance, research and development, foreign investment, and location.

Gashi, Hashi, and Pugh [17] study internal and external factors affecting the SMEs' export behavior in transition economies. The authors used a firm-level dataset from surveys done jointly by the European Bank for Reconstruction and Development and World Bank. The study explains the position of human and technology on SMEs' export participation and intensity. Other aspects, such as size, foreign ownership, industry linkages, external finance, and networking, are also essential in explaining SMEs' export behavior.

Another study on SMEs' export behavior, Pickernell, Jones, Thompson, and Packham [18], examines SME's determinants using the dataset from a survey of the UK Federation of Small Businesses year 2008. The study shows that the industry sector, firms' age, the firms' available resources, human capital, and technology determine SME export performance.

For the Indonesian case, studies on firms' productivity and export behavior are also limited. Wengel and Rodriguez [19] researched the Indonesian manufacturing firms' export behavior. This study uses firm-level data on medium and large manufacturing survey year 2000 from Statistics Indonesia. The study found that larger firms manage to export more than smaller firms. Furthermore, firms situated in the area with more exporters, more access to credit, and more foreign investment, tend to have a higher export share.

Rodríguez-Pose, Tselios, Winkler, and Farole [20] examined the determinant of Indonesia manufacturing firm's export. This study uses the manufacturing census data over the period 19902005. The study found that firms' export behavior is driven by internal factors such as productivity, capital intensity, firms' age, export experience, and foreign ownership share.

Then, Rachbini [21] analyzed the determinant of export behavior of Indonesia SMEs. The author uses a firm-level dataset of SMEs manufacturing firm census in 2006 from Indonesia Statistics. The paper concludes that productivity determines SMEs' export participation. Moreover, factors such as human capital, capital intensity, information, financial access, firm's age, and firm size, business obstacle determine the probability to export.
As mentioned above, Indonesian SMEs are indicated to encounter lower productivity. They dominate the firm structure of business entities and national employment, but their contribution to Gross Domestic Product (GDP) and exports are underachieved. To the best of the authors' knowledge, studies related to firms' productivity and export behavior in Indonesia, mainly using firm-level data analysis, are still limited. Moreover, most of the previous research still focuses on large firms' object or use old dataset.

Given this background, it gives a chance this research to fill the gap in the empirical studies. This study would like to analyze the role of productivity in explaining Indonesian manufacturing firms' export behavior. Compared to the previous studies that have been done, this study focuses on the micro and small firms and uses updated firm-level survey data. Therefore, this study has an excellent opportunity to provide updated findings that are useful in developing Indonesia SMEs' export.

Furthermore, this study proposes a research question: What is the role of firms' productivity in determining Indonesian micro and small manufacturing firms' export behavior? The following hypothesis is tested using the dataset of micro and small manufacturing survey year 2015 from Statistics Indonesia (Badan Pusat Statistik): productivity of Indonesian micro and small manufacturing firms has a positive influence on determining their export behavior. This study found that labor productivity and output to cost ratio positively and significantly determine export participation and intensity even though its marginal effect plays a minor role in the export behavior.

The rest of the paper is structured as follows. Section 2 describes the research method and data used in this study. In section 3 , the results and discussion are analyzed. Last, section 4 provides the conclusion of this study.

\section{RESEARCH METHOD}

This study intends to analyze the role of productivity in micro and small firms' export behavior. Based on the existing literature, export behavior can be proxied by export intensity [16], [17], [21], [22], [23]. The export intensity is defined as the ratio of total export to total output, and this ratio shows a non-negative value, ranging between 0 and 100 . The dataset has a significant fraction of zero value (non-exporting firms). Therefore, this type of data is addressed by the generalized Tobit model [24]. 
Tobit estimation is the most popular in empirical studies on export behavior [22], [23], [25]. Tobit estimation is used to account for influences on the likelihood that firms will decide to export (propensity) and export decisions of existing exporters (intensity). The model is defined as:

$$
\begin{gathered}
y^{*}=\beta_{0}+\beta_{1} x_{1}+\beta_{k} x_{k}+u, u \mid x \sim N\left(0, \sigma^{2}\right) \\
y=\max \left(0, y^{*}\right) \\
y=\left\{\begin{array}{lll}
y^{*} & \text { if } y^{*}>0 \\
0 & \text { if } y^{*} \leq 0
\end{array}\right.
\end{gathered}
$$

The variable $y$ is the unobservable latent variable if $y^{*}$ takes a non-positive value; otherwise, it is observable. In other words, the dependent variable $y$ consists of left-censored and uncensored observations. Then, in equation (1), $x$ are explanatory variables, which containing $x_{1}, x_{2}, \ldots, x_{k}$ variables; $\beta$ is the coefficients to be estimated corresponding with $x$, and $u$ is normally and independently distributed error terms.

Furthermore, there is a diagnostic check suggested by Greene [26] and Wooldridge [24] to assess the validity and the appropriateness of Tobit estimation. They propose that Tobit estimates be divided by the regression's estimated standard error and then compared with the Probit model's respective parameters. The Tobit estimation is valid when the ratio close to the corresponding coefficient estimates in the Probit model. Therefore, this study also employs the Probit model for comparison. The model is a nonlinear model for binary response. In this case, the outcome variable is export participation. The model is defined as:

$\operatorname{Prob}(y=1 \mid x)=G\left(\beta_{0}+\beta_{1} x_{1}+\beta_{k} x_{k}\right)=G(x \beta)$ (2) In equation (2), $y$ is the binary outcome variable, which equals one if the firm participates in export and equals zero if it does not participate. Then, $x$ is a vector containing the $k$ explanatory variables; $\beta$ is the corresponding vector of coefficients to be estimated. $G$ means the response probability is a function of the explanatory variables $x$ 's.

This study uses the micro and small manufacturing survey data year 2015 (VIMK15) from Statistics Indonesia. This dataset shows the small-size enterprises of which employees ranges between one to 19 workers in 2015. There are 58,290 sample firms in this dataset, covering the entire 34 provinces in Indonesia. According to this dataset, micro and small manufacturing firms are distributed in these following subsector food industry (38.80\%), textile and footwear industry $(21.55 \%)$, and wood and furniture industry (18.90\%). Then, firms participating in export activity recorded in this dataset are only 181 firms, which belong to the textile and footwear industry (41.99\%), wood and furniture industry (19.89\%), and food industry $(12.71 \%)$. Details of the distribution are displayed in Table 1.

Table 1. Distribution of micro and small manufacturing firms by subsector

\begin{tabular}{lrr}
\hline \multicolumn{1}{c}{ Subsector } & All Samples & Exporting Firms \\
\hline Food, Beverage, and Tobacco Industry & $38.80 \%$ & $12.71 \%$ \\
Textile and Footwear Industry & $21.55 \%$ & $41.99 \%$ \\
Wood Product and Furniture Industry & $18.90 \%$ & $19.89 \%$ \\
Paper Product and Printing Industry & $1.47 \%$ & $2.76 \%$ \\
Chemical and Rubber Industry & $1.89 \%$ & $2.76 \%$ \\
Non-Metal Mining Industry & $8.80 \%$ & $8.84 \%$ \\
Basic Metal and Metal Product Industry & $4.60 \%$ & $3.31 \%$ \\
Other Manufacturing Industry & $3.99 \%$ & $7.73 \%$ \\
\hline Number of firms & $\mathbf{5 8 , 2 9 0}$ & $\mathbf{1 8 1}$ \\
\hline
\end{tabular}

Source: VIMK 2015 (author compilation)

The advantage of using this dataset is that the number of observations is relatively large. Moreover, this dataset also provides quite comprehensive information related to export activity, which is the primary variable for this study, so this study is visible to be conducted. Meanwhile, in terms of number observation, this dataset has a drawback compared to the census dataset because the census dataset generally has a larger number of samples. As for comparison, the economic census dataset year 2016 has 314,747 observations of micro and small manufacturing firms, in which 900 firms are participating in export. However, the VIMK15 dataset is considered as the most comprehensive and updated one since the last economic census dataset year 2016 for manufacturing firms is not ultimately disseminated by Statistics Indonesia. 
Furthermore, Table 2 shows the description variables in this paper. As the dependent variable, Probit and Tobit model use export participation and export intensity, respectively. Export participation is the binary variable, which equals one if the firm participates in export, otherwise zero. Export intensity is measured by the share of export products to total output.

As the main independent variable, this study focuses on productivity. The productivity is proxied by labor productivity, obtained from the total output value divided by the firm's total employees. Besides, the other measure is that output to costs ratio. This variable captures how much output is generated by one-unit spending on the cost of production. The self-selection hypothesis explains that the higher the firms' production performance, the higher the probability firms engage in exporting. Therefore, this study expects positive signs for the relationships between productivity and export participation and export intensity.

The other factor related to productivity and firms' characteristics, such as capital intensity, financial access, business obstacles, the firm's age, and its size, are used as control variables. Another control variable is human capital, which is proxied by CEO education and employment training. Development support, measured by assistance, partnership, and cooperative member, is also used as the control variable. Table 3 shows the summary statistics of the variables.

Table 2. Description of Variables

\begin{tabular}{|c|c|c|}
\hline Dependent Variable & Description & Expected sign \\
\hline Export Intensity (Tobit) & The ratio of total export to total output & \\
\hline Export Participation (Probit) & $\begin{array}{l}\text { Binary outcome variable. One means the firm } \\
\text { participates in export, otherwise zero }\end{array}$ & \\
\hline \multicolumn{3}{|l|}{ Main Independent Variable } \\
\hline Labor Productivity & The ratio of total output to total labor & \\
\hline $\begin{array}{l}\text { Output to Cost Ratio } \\
\text { Control Variable }\end{array}$ & The ratio of total output to total cost & \\
\hline Capital Intensity & The ratio of total capital to total labor & $(+)$ \\
\hline CEO Education & $\begin{array}{l}\text { Dummy }=1 \text { means CEO graduated from a diploma or } \\
\text { higher-level education, otherwise zero }\end{array}$ & $(+)$ \\
\hline Employment Training & $\begin{array}{l}\text { Dummy }=1 \text { means the firm has joined to any training } \\
\text { for their employee, otherwise zero }\end{array}$ & $(+)$ \\
\hline Financial Access & $\begin{array}{l}\text { Dummy }=1 \text { means the firm has access to financial } \\
\text { institutions, otherwise zero }\end{array}$ & $(+)$ \\
\hline Assistance & $\begin{array}{l}\text { Dummy }=1 \text { means the firm has received assistance } \\
\text { from other institutions, otherwise zero }\end{array}$ & $(+)$ \\
\hline Partnership & $\begin{array}{l}\text { Dummy }=1 \text { means the firm has a partnership in } \\
\text { business, otherwise zero }\end{array}$ & $(+)$ \\
\hline Cooperative Member & $\begin{array}{l}\text { Dummy }=1 \text { means the firm is a member of the } \\
\text { cooperative, otherwise zero }\end{array}$ & $(+)$ \\
\hline Business Obstacle & $\begin{array}{l}\text { Dummy }=1 \text { means firm experiences business } \\
\text { obstacles, otherwise zero }\end{array}$ & $(-)$ \\
\hline Firms' Age & Number of years firm has been established (years) & $(+)$ \\
\hline Firms' Size & Number of total labor (unit worker) & $(+)$ \\
\hline
\end{tabular}

Table 3. Summary Statistics

\begin{tabular}{lcrrrr}
\hline \multicolumn{1}{c}{ Variable } & \multicolumn{1}{c}{ Obs } & \multicolumn{1}{c}{ Mean } & Std. Dev. & \multicolumn{1}{c}{ Min } & \multicolumn{1}{c}{ Max } \\
\hline Export Intensity & 58,290 & 0.149 & 3.328 & 0 & 100 \\
Export Participation & 58,290 & 0.003 & 0.056 & 0 & 1 \\
Labor Productivity & 58,285 & $4,246,746$ & $1.02 \mathrm{E}+07$ & 10,000 & $5.00 \mathrm{E}+08$ \\
Output to Cost Ratio & 58,248 & 3.247 & 8.237 & 0.067 & 590 \\
Capital Intensity & 58,254 & $2.17 \mathrm{E}+07$ & $6.03 \mathrm{E}+07$ & 0 & $5.60 \mathrm{E}+09$ \\
CEO Education & 58,290 & 0.033 & 0.180 & 0 & 1 \\
Emplyoment Training & 58,290 & 0.049 & 0.216 & 0 & 1 \\
Financial Access & 58,290 & 0.089 & 0.285 & 0 & 1 \\
Assistance & 58,290 & 0.047 & 0.212 & 0 & 1 \\
Partnership & 58,290 & 0.093 & 0.290 & 0 & 1
\end{tabular}




\begin{tabular}{lcrrrr}
\hline \multicolumn{1}{c}{ Variable } & \multicolumn{1}{c}{ Obs } & \multicolumn{1}{c}{ Mean } & Std. Dev. & \multicolumn{1}{c}{ Min } & \multicolumn{1}{c}{ Max } \\
\hline Cooperative Member & 58,290 & 0.029 & 0.168 & 0 & 1 \\
Business Obstacle & 58,290 & 0.747 & 0.435 & 0 & 1 \\
Firms' Age & 58,290 & 13.340 & 10.906 & 0 & 115 \\
Firms' Size & 58,290 & 2.318 & 2.158 & 1 & 19 \\
\hline
\end{tabular}

Source: VIMK 2015 (author calculation)

\section{RESULT AND DISCUSSION}

First, this study performs a statistical test to determine the difference between the means of exporting firms and non-exporting firms. This test is conducted for all independent variables. The hypothesis is that exporting firms and nonexporting firms significantly differ in their productivity and characteristic. Table 4 presents the result of the mean difference statistical test for all independent variables. Overall, the results show that exporting firms have characteristics: having larger labor productivity and utilizing more capital, managed by a more educated leader, performing training to upgrade labor skills, receiving more support and assistance, and larger. These results support the study of Bernard and Jensen [6], which explains that exporting firms have improved performance in labor productivity, capital intensity, inputs, and size.

Table 4. Mean Difference Statistical Test

\begin{tabular}{|c|c|c|c|c|c|c|}
\hline $\begin{array}{l}\text { Independent } \\
\text { Variable }\end{array}$ & $\begin{array}{l}\text { Non- } \\
\text { exporting } \\
\text { firms }\end{array}$ & $\begin{array}{l}\text { Exporting } \\
\text { firms }\end{array}$ & Difference & $\begin{array}{c}\text { Prob } \\
(\text { diff }<0)\end{array}$ & $\begin{array}{c}\text { Prob } \\
(\text { diff } \neq 0)\end{array}$ & $\begin{array}{c}\text { Prob } \\
(\text { diff }>0)\end{array}$ \\
\hline (1) & (2) & (3) & $(4)=(2)-(3)$ & (5) & (6) & (7) \\
\hline Labor Productivity & 4224078 & $1.15 \mathrm{E}+07$ & -7299567 & $0.000^{\star \star \star}$ & $0.000^{\star \star *}$ & \\
\hline Output to Cost Ratio & 3.245 & 4.030 & -0.785 & 0.101 & 0.202 & 0.899 \\
\hline Capital Intensity & $2.17 \mathrm{E}+07$ & $3.22 \mathrm{E}+07$ & $-1.05 \mathrm{E}+07$ & 0.009 & 0.019 & 0.990 \\
\hline CEO Education & 0.033 & 0.160 & -0.127 & $0.000^{* * *}$ & $0.000^{* * *}$ & - \\
\hline Employment Training & 0.049 & 0.171 & -0.123 & $0.000^{\star * *}$ & $0.000^{\star * *}$ & - \\
\hline Financial Access & 0.089 & 0.210 & -0.121 & $0.000^{* * *}$ & $0.000^{* * *}$ & - \\
\hline Assistance & 0.047 & 0.110 & -0.064 & $0.000^{* * *}$ & $0.000^{* * *}$ & - \\
\hline Partnership & 0.092 & 0.227 & -0.134 & $0.000^{\star * *}$ & $0.000^{\star * *}$ & - \\
\hline Cooperative Member & 0.029 & 0.116 & -0.087 & $0.000^{* * *}$ & $0.000^{\star * *}$ & - \\
\hline Business Obstacle & 0.747 & 0.740 & 0.007 & 0.587 & 0.827 & 0.413 \\
\hline Firms' Age & 13.337 & 14.022 & -0.685 & 0.200 & 0.399 & 0.801 \\
\hline Firms' Size & 2.310 & 4.967 & -2.657 & $0.000^{\star * *}$ & $0.000^{\star * *}$ & - \\
\hline
\end{tabular}

The study next examines the role of productivity on micro and small firms' export behavior using the Tobit model and Probit model for a diagnostic check purpose. The Tobit, based on equation (1), and Probit model, based on equation (2), are regressed using STATA software. The Tobit model uses export intensity as the dependent variable, while the Probit model uses export participation. The independent variables are the same for both models.

Table 5 shows the estimation result for Tobit and Probit model. Moreover, the table also provides the diagnostic check result. The Tobit estimate is divided by its estimated standard error and then compared with the Probit model's respective parameters. Our finding shows that the ratio in both models is consistent. It indicates that, overall, the Tobit estimation is valid. Moreover, the likelihood ratio chi-square of $216.45(\mathrm{df}=12)$ with a p-value of 0.0000 tells us that our model fits significantly better than an empty model (i.e., a model with no predictors).

The results in Table 5 show that micro and small firms' export participation and export intensity are positively significantly influenced by labor productivity at $1 \%$ level of significance. Moreover, output to cost ratio, which is the other proxy of productivity, also significantly determines export participation and export intensity at $5 \%$ level of significance. Both productivity variables show a positive and significant relationship with export participation and export intensity. Therefore, this finding confirms the hypothesis in this study and support the self-selection hypothesis [6], [7], [8], [9], [10]. 
As for factors related to productivity, human capital, which is assessed by CEO education and employment training, is also positively significant at $1 \%$ in explaining micro and small firms' participation in the export market and its intensity. This finding confirms the study of Gashi, Hashi, and Pugh [17] and Pickernell, Jones, Thompson, and Packham [18] in which human capital factors affect firms' export propensity and intensity through productivity increases.

The other factor related to productivity and firms' characteristics, such as capital intensity, financial access, partnership, cooperative member, firms' age, and firms' size, demonstrate a positive correlation with export participation and export intensity. Nevertheless, the estimated coefficient of capital intensity and financial access is insignificant. The insignificant estimated coefficient of those variables might be because most micro and small manufacturing firms in Indonesia experience more labor-intensive instead of capital-intensive and have limited loan support from financial institutions.

Furthermore, assistance shows an inverse relationship. The relationship sign is different from the expected result. It might be because micro and small manufacturing firms in Indonesia experience drawbacks of getting support from either government or other institutions, such as procedure and administration cost. Besides, having more considerable business obstacles will hamper export performance. Nonetheless, the effect is not significant because the barriers such as raw material, capital, and difficulty in paying labor costs might be common for micro and small manufacturing firms in Indonesia.

Table 5. Tobit Model and Probit Model Estimation

\begin{tabular}{|c|c|c|c|c|c|c|}
\hline \multirow{3}{*}{$\begin{array}{l}\text { Independent Variable } \\
\text { Labor Productivity }\end{array}$} & \multirow{2}{*}{\multicolumn{2}{|c|}{ Tobit Model }} & \multirow{2}{*}{\multicolumn{2}{|c|}{ Probit Model }} & \multicolumn{2}{|c|}{$\begin{array}{l}\text { Diagnostic Check } \\
\text { (Coef./Std. Err.) }\end{array}$} \\
\hline & & & & & Tobit & Probit \\
\hline & $\begin{array}{r}7.50 \mathrm{E}-07 \\
(1.54 \mathrm{e}-07)\end{array}$ & 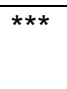 & $\begin{array}{r}5.07 \mathrm{E}-09 \\
(1.01 \mathrm{e}-09)\end{array}$ & *** & 4.844 & 5.020 \\
\hline Output to Cost Ratio & $\begin{array}{r}0.547 \\
(0.236)\end{array}$ & ** & $\begin{array}{r}0.004 \\
(0.002)\end{array}$ & $\star *$ & 2.319 & 2.431 \\
\hline Capital Intensity & $\begin{array}{r}2.94 \mathrm{E}-08 \\
(4.00 \mathrm{e}-08)\end{array}$ & & $\begin{array}{r}2.14 \mathrm{E}-10 \\
(2.68 \mathrm{e}-10)\end{array}$ & & 0.735 & 0.799 \\
\hline CEO Education & $\begin{array}{r}61.503 \\
(13.117)\end{array}$ & $\star \star \star *$ & $\begin{array}{r}0.438 \\
(0.085)\end{array}$ & 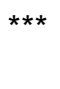 & 4.689 & 5.161 \\
\hline Employment Training & $\begin{array}{r}39.014 \\
(12.716)\end{array}$ & $\star \star \star *$ & $\begin{array}{r}0.287 \\
(0.084)\end{array}$ & 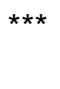 & 3.068 & 3.400 \\
\hline Financial Access & $\begin{array}{r}9.690 \\
(10.981)\end{array}$ & & $\begin{array}{r}0.066 \\
(0.075)\end{array}$ & & 0.882 & 0.870 \\
\hline Assistance & $\begin{array}{r}-15.484 \\
(15.240)\end{array}$ & & $\begin{array}{r}-0.110 \\
(0.104)\end{array}$ & & -1.016 & -1.055 \\
\hline Partnership & $\begin{array}{r}26.234 \\
(10.516)\end{array}$ & ** & $\begin{array}{r}0.178 \\
(0.072)\end{array}$ & $\star \star$ & 2.495 & 2.494 \\
\hline Cooperative Member & $\begin{array}{r}56.452 \\
(15.457)\end{array}$ & 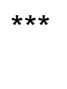 & $\begin{array}{r}0.414 \\
(0.102)\end{array}$ & $\star \star \star *$ & 3.652 & 4.073 \\
\hline Business Obstacle & $\begin{array}{r}-9.591 \\
(8.671)\end{array}$ & & $\begin{array}{r}-0.067 \\
(0.060)\end{array}$ & & -1.106 & -1.121 \\
\hline Firms' Age & $\begin{array}{r}0.591 \\
(0.346)\end{array}$ & * & $\begin{array}{r}0.004 \\
(0.002)\end{array}$ & * & 1.708 & 1.821 \\
\hline Firms' Size & $\begin{array}{r}9.084 \\
(1.149)\end{array}$ & *** & $\begin{array}{r}0.063 \\
(0.007)\end{array}$ & *** & 7.908 & 9.378 \\
\hline Constant & $\begin{array}{r}-452.122 \\
(33.153)\end{array}$ & *** & $\begin{array}{r}-3.105 \\
(0.068)\end{array}$ & *** & & \\
\hline $\begin{array}{l}\text { Observations } \\
\text { Uncensored Obs }\end{array}$ & 58,226 & & 58,226 & & & \\
\hline $\begin{array}{l}\text { Uncensored Obs. } \\
\text { Log likelihood }\end{array}$ & $\begin{array}{r}180 \\
-1986.160\end{array}$ & & -1108.171 & & & \\
\hline LR chi2 & 216.45 & & 223.59 & & & \\
\hline Prob > chi2 & 0.000 & & 0.000 & & & \\
\hline
\end{tabular}




\begin{tabular}{|c|c|c|c|c|}
\hline & & & \multicolumn{2}{|c|}{ (Coef./Std. Err.) } \\
\hline & & & Tobit & Probit \\
\hline Pseudo R2 & 0.052 & 0.092 & & \\
\hline
\end{tabular}

Lastly, the study analyses the marginal effect of the independent variable. Both Tobit and Probit models make use of a latent variable framework. The coefficient estimates reported in the model's estimation can only explain an independent variable's effect on the actual outcome. Still, it cannot tell the magnitude of the effect. This study follows the Average Partial Effects approach for computing the marginal effect's magnitude of each independent variable on both models' actual outcome since this approach is preferred in most cases [24].

Table 6 presents the result of the marginal effect of both models. The marginal effect of labor productivity on export participation and export intensity plays a minor role in the export behavior even though it shows a positive and significant relationship at $1 \%$ and $5 \%$ level of significance.
The marginal effect indicates that when firms increase labor productivity by one unit on average, the probability of being an exporter is minuscule. Moreover, when exporting firms increase labor productivity by one unit on average, there will be an insubstantial increase in the export intensity.

As the other proxy of productivity, the marginal effect of output to cost ratio is also positively significant at $5 \%$ in explaining firms' participation in the export market and its intensity. The magnitude of marginal effect on both export participation and export intensity is minuscule. The finding designates as soon as firms increase output to cost ratio by one unit on average; the possibility of exporting its products in the global market is tiny. The export intensity will expand by an insignificant number once exporter firms boost output to cost ratio by one unit on average.

Table 6. Marginal Effect Tobit Model and Probit Model

\begin{tabular}{|c|c|c|c|c|}
\hline \multirow{2}{*}{$\begin{array}{l}\text { Independent Variable } \\
\text { Labor Productivity }\end{array}$} & \multicolumn{2}{|c|}{ Tobit Model } & \multicolumn{2}{|c|}{ Probit Model } \\
\hline & $\begin{array}{r}2.02 \mathrm{E}-09 \\
(9.41 \mathrm{e}-10)\end{array}$ & ** & $\begin{array}{r}4.41 \mathrm{E}-11 \\
(9.15 \mathrm{e}-12)\end{array}$ & $\star \star \star *$ \\
\hline Output to Cost Ratio & $\begin{array}{r}0.001 \\
(0.001)\end{array}$ & $* *$ & $\begin{array}{l}3.34 \mathrm{E}-05 \\
(1.4 \mathrm{e}-05)\end{array}$ & ** \\
\hline Capital Intensity & $\begin{array}{r}7.94 \mathrm{E}-11 \\
(1.73 \mathrm{e}-10)\end{array}$ & & $\begin{array}{r}1.86 \mathrm{E}-12 \\
(2.34 \mathrm{e}-12)\end{array}$ & \\
\hline CEO Education & $\begin{array}{r}0.166 \\
(0.036)\end{array}$ & $* \star *$ & $\begin{array}{r}0.004 \\
(0.001)\end{array}$ & $* * \star$ \\
\hline Employment Training & $\begin{array}{r}0.105 \\
(0.035)\end{array}$ & $* * *$ & $\begin{array}{r}0.002 \\
(0.001)\end{array}$ & $* * *$ \\
\hline Financial Access & $\begin{array}{r}0.026 \\
(0.030)\end{array}$ & & $\begin{array}{r}0.001 \\
(0.001)\end{array}$ & \\
\hline Assistance & $\begin{array}{r}-0.042 \\
(0.041)\end{array}$ & & $\begin{array}{r}-0.001 \\
(0.001)\end{array}$ & \\
\hline Partnership & $\begin{array}{r}0.071 \\
(0.029)\end{array}$ & ** & $\begin{array}{r}0.002 \\
(0.001)\end{array}$ & ** \\
\hline Cooperative Member & $\begin{array}{r}0.153 \\
(0.042)\end{array}$ & $* * *$ & $\begin{array}{r}0.004 \\
(0.001)\end{array}$ & *** \\
\hline Business Obstacle & $\begin{array}{r}-0.026 \\
(0.023)\end{array}$ & & $\begin{array}{r}-0.001 \\
(0.001)\end{array}$ & \\
\hline Firms' Age & $\begin{array}{r}0.002 \\
(0.001)\end{array}$ & * & $\begin{array}{r}0.000 \\
(0.000)\end{array}$ & * \\
\hline Firms' Size & $\begin{array}{r}0.025 \\
(0.003)\end{array}$ & *** & $\begin{array}{r}0.001 \\
(0.000)\end{array}$ & $* \star *$ \\
\hline
\end{tabular}

The values within the parentheses show the standard errors.

The levels of significance are shown as follows ${ }^{* *} p<0.01,{ }^{* *} p<0.05,{ }^{*} p<0.1$. 


\section{CONCLUSION}

This study tries to examine the role of productivity in explaining Indonesia SMEs' export behavior. This study uses the micro and small manufacturing survey data year 2015 (VIMK15) from Statistics Indonesia. Utilizing the Tobit and Probit model, the study found that firms' productivity, which is proxied by labor productivity and output to cost ratio, positively and significantly determine export participation and export intensity. The empirical results were consistent with the self-selection hypothesis in which firms' productivity positively determine firms' decision to participate in export.

As for factors related to productivity, human capital, which is proxied by CEO education and employment training, positively and significantly determines export participation and intensity. These findings are in line with Gashi, Hashi, and Pugh [17] and Pickernell, Jones, Thompson, and Packham [18], which explains that the human capital, the share of the educated worker, is positively related to SMEs' export participation and intensity.

Based on the major findings, providing appropriate and reasonable employee training might support Indonesia's micro and small manufacturing firms' development. The policymaker could help micro and small firms upgrade their workers' skills by providing appropriate and reasonable technical production, managerial, and marketing training. The permissible tax deduction and the financial supports scheme for vocational training could be another option. Hopefully, when the workers' skill increases, it will contribute to labor productivity and the firm's productivity as well.

As for the managerial aspect, the policymaker should recognize the key concept of export performance. It should consider how to encourage micro and small firms' to be the exporters and think about continuing the competitiveness as exporters overtime. The policymaker might identity the leading commodities export and then attempt to increase its productivity. The policy to improve productivity in the leading commodities export would keep micro and small firms' competitiveness in the export market.

We acknowledge that there are several limitations to this study. First, it is hard to measure firms' export performance precisely since numerous possible factors influence it, such as spillover effect, industrial linkage effect, and global supply chain. Conti, Turco, and Maggioni [27] examine spillovers' role through backward linkages in
Italian firms' export performance. The research found that joining networks with internationalized customers may play an essential role in enhancing firms' exports. Another study on export performance, Beltramello, De Backer, and Moussiegt [28], investigates countries' export performance in the context of the increasing importance of global value chains. The study shows that imports of intermediates increasingly determine the export competitiveness of countries in final products. However, our study does not involve all the possible variables that might influence firms' export performance since the subject of interest in this study is related to the relationship between productivity and export behavior. Second, the VIMK 2015 dataset might be could not describe the latest condition of micro and small manufacturing firms. Therefore, future research is suggested to explore more extensive possible variables that might influence firms' export behavior and use the latest dataset of micro and small manufacturing survey or census when it is already available.

\section{REFERENCES}

[1] The ASEAN Secretariat, ASEAN Economic Community Blueprint 2025. Jakarta: The ASEAN Secretariat, 2015. Available https://www.asean.org/storage/2016/03/A ECBP_2025r_FINAL.pdf.

[2] A. Mourougane, "Promoting SME development in Indonesia," OECD Econ. Dep. Work. Pap., no. 995, pp. 1-38, 2012. Available at: https://www.oecdilibrary.org/content/paper/5k918xk464f7en.

[3] Asian Development Bank, Asia SME Finance Monitor 2014. Manila: Asian Development Bank, 2015. Available at: https://www.adb.org/sites/default/files/publ ication/173205/asia-sme-financemonitor2014.pdf.

[4] J. Wagner, "Exports and productivity: a survey of the evidence from firm-level data," World Econ., vol. 30, no. 1, pp. 6082, 2007. Available at doi: 10.1111/j.14679701.2007.00872.x.

[5] J. I. Haidar, "Trade and productivity: selfselection or learning-by-exporting in India," Econ. Model., vol. 29, no. 5, pp. 17661773 , 2012. Available at doi: 10.1016/j.econmod.2012.05.005. 
[6] A. B. Bernard and J. Bradford Jensen, "Exceptional exporter performance: cause, effect, or both?," J. Int. Econ., vol. 47, no. 1, pp. $1-25$, 1999. Available at doi: 10.1016/S0022-1996(98)00027-0.

[7] M. A. Delgado, J. C. Fariñas, and S. Ruano, "Firm productivity and export markets: a non-parametric approach," $\mathrm{J}$. Int. Econ., vol. 57, no. 2, pp. 397-422, 2002. Available at doi: $10.1016 / \mathrm{S} 0022-$ 1996(01)00154-4.

[8] J. M. Arnold and K. Hussinger, "Export behavior and firm productivity in German manufacturing: a firm-level analysis," Rev. World Econ., vol. 141, no. 2, pp. 219-243, 2005. Available at doi: $10.1007 / \mathrm{s} 10290$ 005-0026-8.

[9] J. Monreal-Pérez, A. Aragón-Sánchez, and G. Sánchez-Marín, "A longitudinal study of the relationship between export activity and innovation in the Spanish firm: the moderating role of productivity," Int. Bus. Rev., vol. 21, no. 5, pp. 862-877, 2012. Available at doi: 10.1016/j.ibusrev.2011.09.010.

[10] J. Deshmukh and P. K. Pyne, "Labour productivity and export performance: Firmlevel evidence from Indian manufacturing industries since 1991," ARTNet Working Paper Series, vol.126, pp.1-25, 2013. Available at: https://www.econstor.eu/handle/10419/10 3869.

[11] B. Cassiman, E. Golovko, and E. MartínezRos, "Innovation, exports and productivity," Int. J. Ind. Organ., vol. 28, no. 4, pp. 372 376, 2010. Available at doi: 10.1016/j.jijindorg.2010.03.005.

[12] Y. Todo, "Quantitative evaluation of the determinants of export and FDI: firm-level evidence from Japan," World Econ., vol. 34, no. 3, pp. 355-381, 2011. Available at doi: 10.1111/j.1467-9701.2011.01331.x.

[13] T. N. Srinivasan and V. Archana, "Determinants of export decision of firms," Econ. Polit. Wkly., vol. 46, no. 7, pp. 4958, 2011. Available at: https://www.jstor.org/stable/27918147.

[14] L. A. Ricci and F. Trionfetti, "Productivity, networks, and export performance: evidence from a cross-country firm dataset," Rev. Int. Econ., vol. 20, no. 3, pp. 552-562, 2012. Available at doi: 10.1111/j.1467-9396.2012.01038.x.

[15] S. Mallick and Y. Yang, "Productivity performance of export market entry and exit: evidence from Indian firms," Rev. Int. Econ., vol. 21, no. 4, pp. 809-824, 2013. Available at doi: 10.1111/roie.12072.

[16] Y. Amornkitvikai, C. Harvie, and T. Charoenrat, "Factors affecting the export participation and performance of Thai manufacturing small and medium sized enterprises (SMEs)," in International Council for Small Business World Conference, 2012, pp. 1-35. Available at: https://ro.uow.edu.au/commpapers/1041/.

[17] P. Gashi, I. Hashi, and G. Pugh, "Export behaviour of SMEs in transition countries," Small Bus. Econ., vol. 42, no. 2, pp. 407435, 2014. Available at doi: 10.1007/s11187-013-9487-7.

[18] D. Pickernell, P. Jones, P. Thompson, and G. Packham, "Determinants of SME exporting," Int. J. Entrep. Innov., vol. 17, no. 1 , pp. 31-42, 2016. Available at doi: 10.5367/ijei.2016.0208.

[19] J. ter Wengel and E. Rodriguez, "SME export performance in Indonesia after the crisis," Small Bus. Econ., vol. 26, no. 1, pp. 25-37, 2006. Available at doi: 10.1007/s11187-004-6491-y.

[20] A. Rodríguez-Pose, V. Tselios, D. Winkler, and T. Farole, "Geography and the determinants of firm exports in Indonesia," World Dev., vol. 44, pp. 225-240, 2013. Available at doi: 10.1016/j.worlddev.2012.12.002.

[21] E. M. Rachbini, "Export determinants of micro and small Enterprises: an empirical evidence of Indonesia manufacturing sector," J. Grad. Sch. Asia-Pacific Stud., vol. 32, no. 9, pp. 1-18, 2016. Available at: https://waseda.repo.nii.ac.jp/?action=repo sitory_action_common_download\&item_id $=25912 \&$ item_no $=1$ \&attribute_id $=162 \&$ file no $=1$.

[22] $\bar{D}$. C. Fonchamnyo and V. A. Wujung, "Innovation and export performance: an empirical insight on the fffect of innovation 
on manufacturing firms in Cameroon," Appl. Econ. Financ., vol. 3, no. 4, pp. 123133, 2016. Available at doi: 10.11114/aef.v3i4.1682.

[23] N. Bashiri Behmiri, J. F. Rebelo, S. Gouveia, and P. António, "Firm characteristics and export performance in Portuguese wine firms," Int. J. Wine Bus. Res., vol. 31, no. 3, pp. 419-440, 2019. Available at doi: 10.1108/IJWBR-07-20180032.

[24] J. M. Wooldridge, Introductory Econometrics: A Modern Approach, 5th ed. Mason: South-Western, 2012. Available at: https://economics.ut.ac.ir/documents/3030 266/14100645/Jeffrey_M._Wooldridge_Int roductory_Econometrics_A_Modern_Appr oach_2012.pdf.

[25] D. Fu, Y. Wu, and Y. Tang, "The effects of ownership structure and industry characteristics on export performance," in International Congress on Modelling and Simulation, Dec. 2011, pp. 1-23. Available at doi: $10.36334 /$ modsim.2011.D12.fu.

[26] W. H. Greene, Econometric Analysis, Fifth Edit. New Jersey: Prentice Hall, 2002. Available at: https://spu.fem.uniag.sk/cvicenia/ksov/obt ulovic/Manaž. štatistika a ekonometria/EconometricsGREENE.pdf.

[27] G. Conti, A. Lo Turco, and D. Maggioni, "Spillovers through backward linkages and the export performance of business services. Evidence from a sample of Italian firms," Int. Bus. Rev., vol. 23, no. 3, pp.
552-565, 2014. Available at doi: 10.1016/j.ibusrev.2013.09.003.

[28] A. Beltramello, K. De Backer, and L. Moussiegt, "The export performance of countries within global value chains," OECD Sci. Technol. Ind., no. 02, pp. 1-46, 2012. Available at doi: $10.1787 / 18151965$.

\section{Acknowledgments}

I convey my appreciation to the Finance Education and Training Agency (FETA)-Ministry of Finance for the master scholarship. I also want to thank the Lab Computing of the Department of EconomicsUniversitas Indonesia for allowing me to work with the micro and small manufacturing survey year 2015 (VIMK 2015) dataset.

\section{Author Biography}

\section{Edi Kiswanto}

was born in Pati on May 17, 1984. The author completed the Diploma IV Accounting Program at

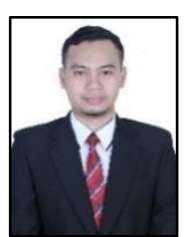
the College of State Accountancy (STAN) in 2010. The author is currently registered as a civil servant in the Directorate General of Taxes, Ministry of Finance. The author received a scholarship from the FETA-Ministry of Finance to continue his studies at the master level. The author is currently completing a joint master's degree at Master of Economics Planning and Development Policy-Universitas Indonesia and Master of Public Management and Administration Course-Rikkyo University. The author can be contacted at the e-mail address: edi.kiswanto.ui@gmail.com. 